\title{
DATING ANOMALIES IN THE ARCHAEOLOGY OF THE 7TH CENTURY BC
}

\author{
Robert M Porter \\ Retired, 11 Havelock Road, Croydon CR0 6QQ, United Kingdom. Corresponding author. Email: rporter@talktalk.net. \\ Michael W Dee \\ RLAHA, Dyson Perrins Building, South Parks Road, Oxford OX1 3QY, United Kingdom.
}

\begin{abstract}
Two recently published sets of radiocarbon dates, one from Mesopotamia and one from Anatolia, gave anomalous results. On the basis of historical analysis, both sets were expected to date to the 7 th century $\mathrm{BC}$. However, the ${ }^{14} \mathrm{C}$ results were more than a century older than this. We tested samples from an Egyptian mummy, also historically dated to the 7 th century BC, to see if such discrepancies were more widespread at this time. We did not find evidence of such a problem, but the results do provide insights into the reuse of old wood in ancient Egyptian coffins. We include publication of an earlier set of dates from the same mummy and coffin set.
\end{abstract}

\section{INTRODUCTION}

Taylor et al. (2010) published some anomalous results for the destruction of the ancient Assyrian capital, Nineveh. The destruction is known to have taken place in $612 \mathrm{BC}$, a key date in ancient history as it effectively ended the Neo-Assyrian Empire (see Oates 1991). A set of 9 radiocarbon dates (done at the University of California, Irvine) on bones from 3 skeletons, which were buried in the final collapse of one of the city's gateways, gave a result in the region of $790 \mathrm{BC}$ (weighted average of 9 samples was $2590 \pm 12 \mathrm{BP}$ ), which is about $180 \mathrm{yr}$ too early. The interdisciplinary team considered several possible causes of error but were able to eliminate every one except the possibility that the occupants of Nineveh had subsisted on a high fish diet, which could have increased the ages by way of a riverine reservoir effect (see Cook et al. 2001).

A recently published set of dates from Gordion in Anatolia also caused surprise. A destruction level from the Early Phrygian town had been dated to the early 7 th century BC and was assumed to have been caused by invading Cimmerians (Mellink 1991 gives 695 BC; later dates have also been suggested). A set of 15 short-lived ${ }^{14} \mathrm{C}$ dates from the destruction layer (done at the University of Heidelberg) centered on the late 9th century BC, roughly $120 \mathrm{yr}$ earlier than previously thought (Manning and Kromer 2011). Unlike Nineveh, however, the historical date for the Gordion destruction is less secure and in fact may prove to be unrelated to the Cimmerians. Nevertheless, the results presented a direct challenge to an archaeological/historical dating system that had been in place for many decades. The object of our research was to determine whether the dates from Nineveh and Gordion were the result of laboratory error, a deficiency of the calibration data over this period, or the result of the misassociation of these samples with historical events of the 7th century BC.

\section{OUR SAMPLES}

Although we aimed to find a historically well-dated Egyptian specimen from the 7th century BC, this proved more difficult than first thought. The exportation of archaeological material from Egypt is currently prohibited, so our search was limited mainly to European museums. A further difficulty involved locating a suitably dated short-lived specimen that was not too valuable to have a piece removed, or so heavily conserved that it might not give a reliable result. Eventually, Silvio Frigg, the manager with responsibility for conservation at the Stiftsbibliothek Museum, St. Gallen, Switzerland, kindly agreed to supply a piece of textile from the mummy of a woman named Shepenese whose richly decorated inner coffin can be stylistically dated to the first half of the 7th century BC

C 2013 by the Arizona Board of Regents on behalf of the University of Arizona Proceedings of the 21st International Radiocarbon Conference edited by A J T Jull \& C Hatté RADIOCARBON, Vol 55, Nr 2-3, 2013, p 1371-1376 


\section{$R M$ Porter \& $M W$ Dee}

(Siegmann 2007; Küffer 2011). Historically dating artifacts like this is a very specialized field; however, this assignment is the best estimate of Dr John Taylor of the British Museum, one of the leading experts on such styles (Taylor 2003). The inner coffin is made of sycamore and the outer of tamarisk, both trees found locally in Egypt (Siegmann 2007). The mummy and its coffins were brought to St. Gallen from Luxor (ancient Thebes) in southern Egypt in AD 1820. The head was unwrapped at that time, and the assemblage later moved to the Stiftsbibliothek in AD 1836 (Siegmann 2007). Stiftsbibliothek supplied 2 pieces of linen cloth cut from one of the outer cover sheets of the mummy wrappings, which had been removed in AD 1820. We also tested some crumbly fragments of wood, but their original location within the mummy and coffin assemblage was imprecise (it is possible they were included for their aromatic quality, or in the mummification process to fill out the mouth and cheeks). These were all sent for dating to the Oxford Radiocarbon Accelerator Unit (ORAU).

\section{EXPERIMENTAL}

Mummy wrappings and coffin wood are commonly infused with organic additives likely to remain impervious to the standard ${ }^{14} \mathrm{C}$ aqueous pretreatment procedure (see Dee et al. 2012). Thus, as a precaution, each of the samples was first solvent washed as follows: acetone $\left(45 \mathrm{~min}, 45^{\circ} \mathrm{C}\right)$, methanol ( $45 \mathrm{~min}, 45^{\circ} \mathrm{C}$ ), and chloroform $\left(45 \mathrm{~min}, 20^{\circ} \mathrm{C}\right.$ ). The cellulosic fraction was then extracted using ORAU's routine pretreatment process (Brock et al. 2010). Briefly, the procedure involved 4 treatments: acid ( $\left.1 \mathrm{M} \mathrm{HCl}, 80^{\circ} \mathrm{C}, 20 \mathrm{~min}\right)$, base $\left(0.2 \mathrm{M} \mathrm{NaOH}, 80^{\circ} \mathrm{C}, 20 \mathrm{~min}\right)$, acid $\left(1 \mathrm{M} \mathrm{HCl}, 80^{\circ} \mathrm{C}\right.$, $20 \mathrm{~min}$ ), and oxidation (acidified $\mathrm{NaClO}_{2}, 20-80^{\circ} \mathrm{C}, 20 \mathrm{~min}$ ). The strength of the oxidant employed in the final step on the coffin wood was $5 \%$ (w: vol) and the textile $2.5 \%$ (w: vol). The resultant holocellulose fractions were freeze-dried overnight. Approximately 5-mg samples were then combusted in an elemental analyzer coupled to a mass spectrometer, which measured the $\delta^{13} \mathrm{C}$ value. The $\mathrm{CO}_{2}$ produced was collected cryogenically, graphitized, and dated at ORAU's AMS facility (see Bronk Ramsey et al. 2004). It is standard practice at ORAU to prepare known-age materials with every batch of unknown samples to ensure no contamination goes undetected during chemical pretreatment, combustion, or measurement.

\section{RESULTS}

The measurements obtained by ORAU on the 2 pieces of mummy wrappings and the fragments of wood are given in Table 1. The calibration of the linen results incorporated the $19 \pm 5 \mathrm{yr}$ offset for short-lived plants proposed by Dee et al. (2010), but as this effect has yet to be demonstrated in indigenous tree species this was not applied to the wood sample. However, the application of this adjustment is merely a matter of procedural consistency. If it were excluded from the calibration of the linen measurements, the absolute date ranges ( $95 \%$ probability) would shift by less than 10 calendar yr.

Table 1 The ${ }^{14} \mathrm{C}$ dates obtained by ORAU in 2012 on wrappings and wood from the Egyptian mummy, Shepenese. Note that the 2 cloth calibrated dates incorporate the $19 \pm 5 \mathrm{yr}$ seasonal offset. In simple terms, this means $3 \mathrm{~A}$ and $5 \mathrm{~A}$ are calibrated as if the ${ }^{14} \mathrm{C}$ measurements are unsystematically too high by $19 \pm 5 \mathrm{yr}$.

\begin{tabular}{llllll}
\hline Sample $\mathrm{nr}$ & Material & $\begin{array}{l}{ }^{14} \mathrm{C} \text { date } \\
(\mathrm{yr} \mathrm{BP}) 1 \sigma\end{array}$ & $\begin{array}{l}\text { Calibrated date } \\
(\text { year BC, 95\%) }\end{array}$ & $\begin{array}{l}\text { Lab nr } \\
(\mathrm{OxA}-)\end{array}$ & $\begin{array}{l}\delta^{13} \mathrm{C} \\
(\% 0, \mathrm{PDB})\end{array}$ \\
\hline 3A & Mummy wrappings & $2539 \pm 26$ & $792-542$ & 26265 & -23.9 \\
5A & Mummy wrappings & $2553 \pm 26$ & $795-546$ & 26266 & -23.9 \\
W & Wood sample & $2731 \pm 27$ & $925-815$ & 26360 & -21.9 \\
\hline
\end{tabular}




\section{PREVIOUS ANALYSIS}

While the 2 cloth tests were in progress, it was discovered that linen wrappings and wood from the inner and outer coffins had already been AMS dated in February 1995 by ETH Zurich. Abbreviated results, without the full $95 \%$ probability date ranges, were included in one of the museum's own publications (Siegmann 1998; full results were contained in a letter sent by Dr Bonani to Dr Dora at Stiftsbibliothek, dated 30 May 1995). Seven dates were made at this time, including 4 on coffin wood and 3 on mummy wrappings. The wood samples A and B were obtained from slots (where pegs once held the lid to the coffin trough) on the upper right-hand side of the inner coffin and similarly from the coffin lid. Samples C and D came from the outer coffin trough on the upper left side, and from the top slot of its lid, respectively. Sample E was from inner bandaging under the back of the mummy. The mummy was originally covered in large outer shrouds from which sample F was obtained, and these were fixed on with outer bandages from which sample $G$ was obtained. The full results of these earlier tests, including their 95\% calibrated ranges (against IntCal09; Reimer et al. 2009), are given in Table 2 below. Once more the minor adjustment proposed by Dee et al. (2010) was only applied to the textile results. The combined results of the analyses by ORAU and ETH Zurich are plotted using OxCal (Bronk Ramsey 2009) in Figure 1.

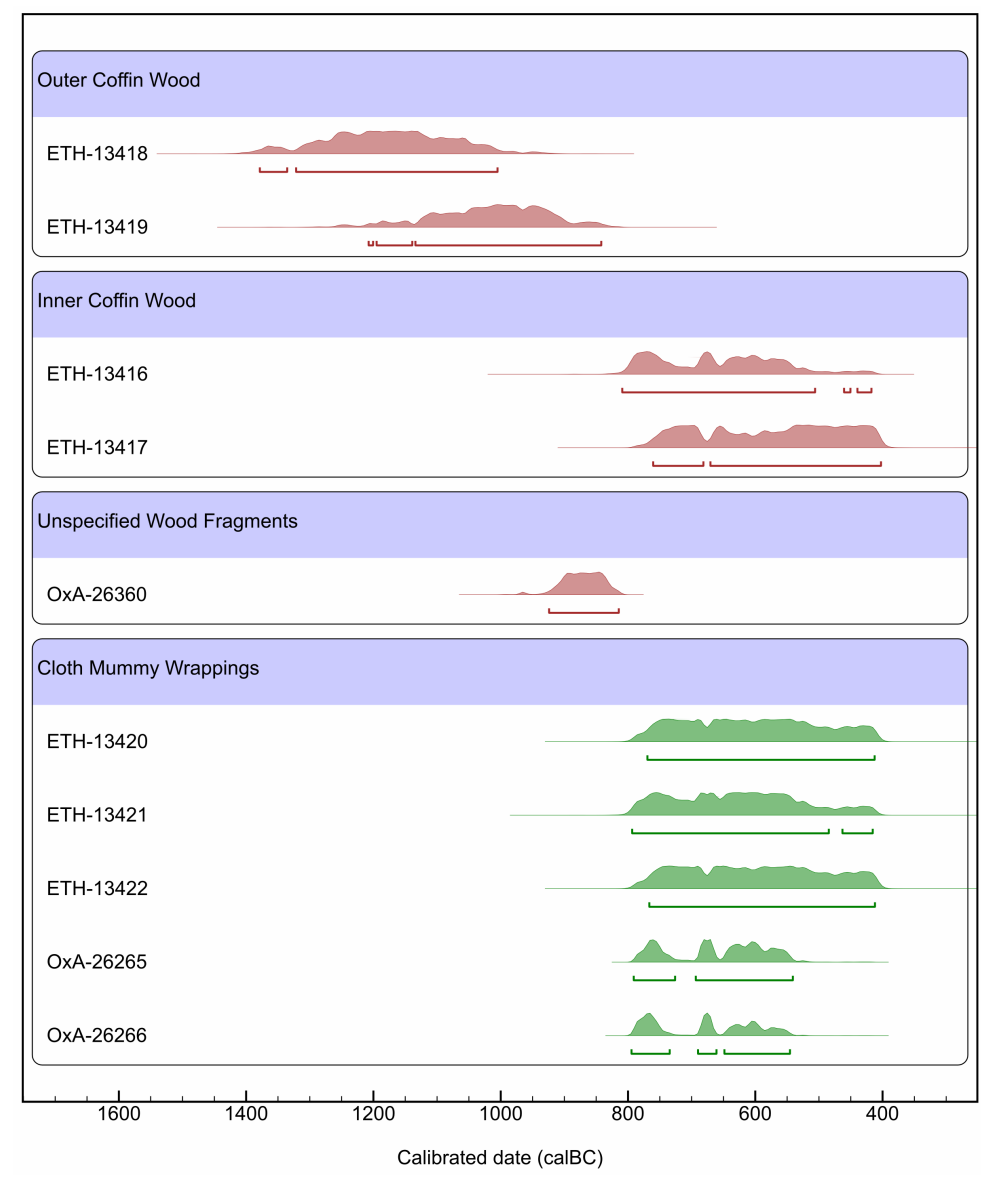

Figure 1 All of the measurements made to date on the Egyptian mummy Shepenese, grouped by component of the overall artifact. 


\section{$R M$ Porter \& $M W$ Dee}

Table 2 The ${ }^{14} \mathrm{C}$ dates obtained by ETH Zurich in 1995 on wrappings and coffin wood of the Egyptian mummy Shepenese. Note that the 3 cloth dates incorporate the $19 \pm 5\left({ }^{14} \mathrm{C} \mathrm{yr}\right)$ seasonal offset (Dee et al. 2010).

\begin{tabular}{lllcll}
\hline $\begin{array}{l}\text { Sample } \\
\mathrm{nr}\end{array}$ & Material & $\begin{array}{l}{ }^{14} \mathrm{C} \text { date } \\
(\mathrm{yr} \mathrm{BP}) 1 \sigma\end{array}$ & $\begin{array}{l}\text { Calibrated date } \\
(\text { year BC, 95\%) }\end{array}$ & $\begin{array}{l}\text { Lab nr } \\
(\mathrm{ETH}-)\end{array}$ & $\begin{array}{l}\delta^{13} \mathrm{C} \\
(\% \circ, \text { PDB })\end{array}$ \\
\hline $\mathrm{A}$ & Inner coffin wood & $2540 \pm 55$ & $810-418$ & 13416 & -20.2 \\
$\mathrm{~B}$ & Inner coffin wood (lid) & $2440 \pm 55$ & $761-403$ & 13417 & -20.5 \\
$\mathrm{C}$ & Outer coffin wood & $2955 \pm 60$ & $1379-1006$ & 13418 & -22.3 \\
$\mathrm{D}$ & Outer coffin wood (lid) & $2840 \pm 60$ & $1208-843$ & 13419 & -21.9 \\
$\mathrm{E}$ & Underside mummy wrappings & $2495 \pm 55$ & $770-413$ & 13420 & -21.2 \\
$\mathrm{~F}$ & Cloth shroud & $2525 \pm 55$ & $794-416$ & 13421 & -21.1 \\
$\mathrm{G}$ & Outer mummy wrappings & $2490 \pm 55$ & $767-413$ & 13422 & -24.3 \\
\hline
\end{tabular}

\section{DISCUSSION}

The ${ }^{14} \mathrm{C}$ results given here of most interest to the question of regionalized offsets in the 7 th century $\mathrm{BC}$ are the textile dates, as the plant material from which they were fashioned was comparatively short-lived. The wood measurements, on the other hand, provide interesting but historically explicable information on the composition of dynastic Egyptian coffins.

The comparative broadness of many of the absolute dates obtained was largely the result of the mid1st millennium Hallstatt plateau (Becker and Kromer 1993). This impediment is inherent in the reference data over this time period and means improvements in measurement precision yield little reward on the absolute timescale (see Figure 2). On the other hand, as observed by Taylor et al. (2010), it also means an uplift of just 80 yr or so in the ${ }^{14} \mathrm{C}$ measurement could result in a 7 th century $\mathrm{BC}$ sample avoiding the plateau altogether and dating some $200 \mathrm{yr}$ too early. The implication is that the observed offsets may be the result of much subtler issues than the absolute dates would suggest.

Nonetheless, all the textile dates we obtained on the mummy of Shepenese were fully compatible with estimates made on historical grounds. As shown in Figure 2, the $2 \sigma$ ranges all overlap the calibration curve during the first half of the 7 th century $\mathrm{BC}$, and the measurements were all highly internally consistent. Calibration of the results without the proposed seasonal effect made no discernable difference. Thus, it can be concluded that our data are consistent with the calibration curve over this part of the record. Furthermore, this finding is in keeping with historical expectation, as Shepenese was from a high social class (as shown by her richly decorated coffin and well-wrapped mummy), so it would have been unusual if the linen used had not been new at the time of burial.

Does this finding throw any light on the surprising results from Nineveh and Gordion? The sacking of Nineveh took place in 612 BC. At $95 \%$ probability, all but 1 of the measurements made on skeletal remains by Taylor et al. (2010) failed to encompass this date. None of the textile dates from the mummy of Shepenese showed such a large discrepancy. Therefore, the dating of the Nineveh individuals is most likely to have been affected by some unsystematic offset, such as high fish consumption (see Cook et al. 2001), although there is little isotopic $\left(\delta^{15} \mathrm{~N}\right.$ and $\left.\delta^{13} \mathrm{C}\right)$ or archaeological evidence for such a scenario. This conundrum was discussed in the original publication but was unable to be fully resolved due to the lack of a relevant suite of stable isotope data for the region. Along similar lines, if a regional anomaly in the calibration curve at the time of the destruction of Gordion were real, then our textile dates should be incompatible with their historical attribution. Our results imply there is no region-wide effect that could have caused the apparent discrepancy presented by the samples obtained by Manning and Kromer (2011). Hence, we suggest the most parsimonious explanation is that they do not relate to a destruction event of the early 7 th century. 


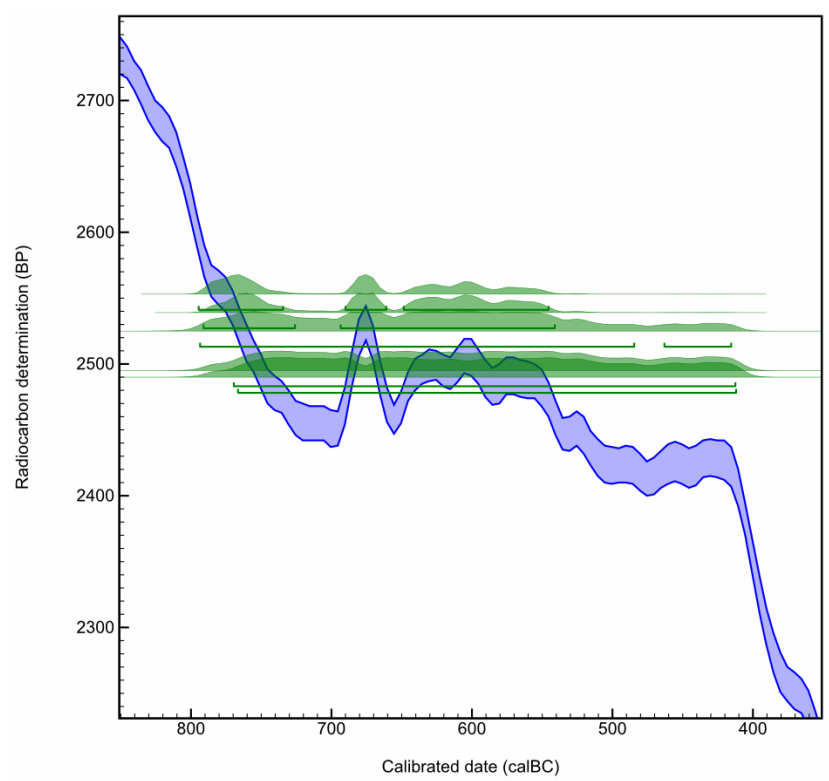

Figure 2 The measurements made on Shepenese's mummy wrappings (95\% probability ranges) plotted against the calibration curve data. The calibrations are positioned on the ${ }^{14} \mathrm{C}$ axis in accordance with their measured ${ }^{14} \mathrm{C}$ dates, but their absolute date ranges incorporate the $19 \pm 5 \mathrm{yr}$ seasonal offset (Dee et al. 2010).

The results on the wooden items obtained by both ORAU and ETH Zurich were at first surprising, with some of the dates being centuries older than the textiles. However, a clear explanation may be put forward for this pattern. In ancient Egypt, wood was a valuable resource and was extensively recycled (Siegmann 1998; Dee et al. 2012). Moreover, the aridity of Upper Egypt lent itself to the reuse of material because the problem of decay was greatly reduced. Each coffin or lid was typically assembled from 5 main parts, but each of these parts was often made up from smaller pieces. The parts were joined together with glue, dowels, or mortise and tenons (Niwinski 1988; Ikram and Dodson 1998). Thus, it is certainly possible that wood of various ages could be assembled into 1 coffin. For example, the older dates obtained for the outer coffin are explicable on the grounds of reuse or refurbishment, or, if newly made, an object that incorporated some very old wood. The inner coffin, on the other hand, seems to have been made of either new or more recently obtained wood. Its dates (ETH-13416 and ETH-13417) are among the youngest obtained, and contemporary with the textile results, despite the fact that some tree rings must have been shaved off during manufacture and the slot sampled did not include the youngest tree rings in the artifact.

We also considered the possibility that the coffins and mummy might not form an original set due to early 19th century antiquities dealers mixing mummies and coffins to increase their profits. However, this seems very unlikely for several reasons. Firstly, both the inner and outer coffins exhibit the name Shepenese. Moreover, it would be highly unlikely that the linen of the substituted mummy would then offer the same ${ }^{14} \mathrm{C}$ date as the inner coffin, and not something entirely different. Lastly, the very similar mummy and coffin set of Pestjenef, who was probably Shepenese's father (Siegmann 2007), was transported to Berlin the same year Shepenese arrived in St. Gallen. Records suggest both these mummies came from a well-known source of authentic mummy and coffin sets at Deir el-Bahri, near modern-day Luxor (Siegmann 2007). 


\section{$R M$ Porter \& $M W$ Dee}

\section{CONCLUSIONS}

The results presented here on a 7th century BC mummy from Egypt fail to corroborate the offsets obtained for the same period of time in recent studies of sites of the ancient Near East. However, the wood used in the construction of the mummy's coffins exhibits the mix of ages commensurate with restoration and recycling.

\section{ACKNOWLEDGMENTS}

We gratefully thank Stiftsbibliothek, St. Gallen, Switzerland; Georges Bonani of ETH, Zurich; and Renate Siegmann of the Swiss Coffin Project (www.e-coffins.ch; she initiated the 1990s project to scientifically analyze the mummy and coffins) for permission to publish the 1995 radiocarbon measurements; and Stiftsbibliothek, especially Silvio Frigg, for their willingness to supply the 2012 samples and permission to publish.

\section{REFERENCES}

Becker B, Kromer B. 1993. The continental tree-ring record - absolute chronology, ${ }^{14} \mathrm{C}$ calibration and climate change at $11 \mathrm{ka}$. Paleogeography, Paleoclimatology, Paleoecology 103(1-2):67-71.

Brock F, Higham TFG, Ditchfield P, Bronk Ramsey C. 2010. Current pretreatment methods for AMS radiocarbon dating at the Oxford Radiocarbon Accelerator Unit (ORAU). Radiocarbon 52(1):103-12.

Bronk Ramsey C. 2009. Bayesian analysis of radiocarbon dates. Radiocarbon 51(1):337-60.

Bronk Ramsey C, Higham TFG, Leach P. 2004. Towards high-precision AMS: progress and limitations. Radiocarbon 46(1):17-24.

Cook GT, Bonsall C, Hedges REM, McSweeney K, Boroneant V, Pettitt PB. 2001. A freshwater diet-derived ${ }^{14} \mathrm{C}$ reservoir effect at the Stone Age sites in the Iron Gates Gorge. Radiocarbon 43(2A):453-60.

Dee MW, Brock F, Harris SA, Bronk Ramsey C, Shortland AJ, Higham TFG, Rowland JM. 2010. Investigating the likelihood of a reservoir offset in the radiocarbon record for ancient Egypt. Journal of Archaeological Science 37(4):687-93.

Dee MW, Rowland JM, Higham TFG, Shortland AJ, Brock F, Harris SA, Bronk Ramsey C. 2012. Synchronising radiocarbon dating and the Egyptian historical chronology through improved sample selection. Antiquity 86(333):868-83.

Ikram S, Dodson A. 1998. The Mummy in Ancient Egypt. London: Thames and Hudson.

Küffer A. 2011. The Swiss Coffin Project. Kmt: A Modern Journal of Ancient Egypt 22(3):18-34.

Manning SW, Kromer B. 2011. Radiocarbon dating Iron Age Gordion and the early Phrygian destruction in particular. In: Rose CG, Darbyshire G, editors. The New Chronology of Iron Age Gordion. Philadelphia: University of Pennsylvania Museum of Archaeology and Anthropology. p 123-53.

Mellink M. 1991. The Phrygian kingdom. In: Boardman J, Edwards IES, Sollberger E, Hammond NGL, edi- tors. The Cambridge Ancient History. Volume III, Part 2, The Assyrian and Babylonian Empires and other States of the Near East from the Eighth to the Sixth Centuries B.C. Cambridge: Cambridge University Press. p 622-42.

Niwinski A. 1988. 21 $1^{\text {st }}$ Dynasty Coffins from Thebes. Mainz am Rhein: P. von Zabern.

Oates J. 1991. Sin-sharra-ishkun (623-612 B.C.). In: Boardman J, Edwards IES, Sollberger E, Hammond NGL, editors. The Cambridge Ancient History. Volume III, Part 2, The Assyrian and Babylonian Empires and other States of the Near East from the Eighth to the Sixth Centuries B.C. Cambridge: Cambridge University Press. p 175-82.

Reimer PJ, Baillie MGL, Bard E, Bayliss A, Beck JW, Blackwell PG, Bronk Ramsey C, Buck CE, Burr GS, Edwards RL, Friedrich M, Grootes PM, Guilderson TP, Hajdas I, Heaton T, Hogg AG, Hughen KA, Kaiser KF, Kromer B, McCormac FG, Manning SW, Reimer RW, Richards DA, Southon JR, Talamo S, Turney CSM, van der Plicht J, Weyhenmeyer CE. 2009. IntCal09 and Marine09 radiocarbon age calibration curves, 0-50,000 years cal BP. Radiocarbon 51(4): $1111-50$.

Siegmann R. 1998. Part 2. In: Müller P, Siegmann R. 1998. Schepenese: Die ägyptische Mumie der Stiftsbibliothek St. Gallen. St. Gallen: Stiftsbibliothek.

Siegmann R. 2007. Chapter II:2. In: Küffer A, Siegmann R. Unter dem Schutz der Himmels-Göttin. Zurich: Chronos.

Taylor J. 2003. Theban coffins from the Twenty-second to the Twenty-sixth dynasty: dating and synthesis of development. In: Strudwick N, Taylor J, editors. The Theban Necropolis. London: British Museum. p 95-121.

Taylor RE, Beaumont WC, Southon J, Stronach D, Pickworth D. 2010. Alternative explanations for anomalous ${ }^{14} \mathrm{C}$ ages on human skeletons associated with the 612 BCE destruction of Nineveh. Radiocarbon 52(2): 372-82. 